\title{
Chemical Composition and Botanical Origin of Red Propolis, a New Type of Brazilian Propolis
}

\author{
Bruno B. Silva1, Pedro L. Rosalen ${ }^{1}$, Jaime A. Cury ${ }^{1}$, Masaharu Ikegaki ${ }^{2}$, \\ Vinícius C. Souza ${ }^{3}$, Alessandro Esteves ${ }^{4}$ and Severino M. Alencar ${ }^{3}$ \\ ${ }^{1}$ Piracicaba Dentistry School (FOP/UNICAMP), Department of Physiologic Science, C.P. 52; Zip-code: 13414-903, \\ Piracicaba, SP, ${ }^{2}$ Federal University of Alfenas; Zip-code 37130-000, Alfenas, MG, ${ }^{3}$ College of Agriculture 'Luiz de \\ Queiroz' (ESALQ/USP), C.P. 9; ZIP-CODE: 13418-900, Piracicaba, SP and ${ }^{4}$ Apiários Almar e Essenciale LTDA, \\ Maceió, AL, Brazil
}

\begin{abstract}
Red propolis is a new type of Brazilian propolis. This material, as well as the secretions of 20 plant species that are often mentioned as its probable botanical source, have been investigated by RP-HPTLC. Phytochemical evidence based on UV-VIS spectra, RP-HPLC and GC-MS, showed Dalbergia ecastophyllum (L.) Taub. to be the main source of red propolis in Alagoas state. The propolis and plant resin showed high relative percentages of the isoflavonoids 3Hydroxy-8,9-dimethoxypterocarpan and medicarpin. To our knowledge this is the first report of the secretion of a leguminous species being the source of propolis.
\end{abstract}

Keywords: Dalbergia ecastophyllum-isoflavonoids-plant resin-red propolis

\section{Introduction}

Brazilian propolis is a non-toxic resinous substance, collected from plant buds or exudates by Apis mellifera bees, which was classified into 12 types according to physicochemical properties and related to geographic locations; however, the botanical origin of only three types were identified (1). The main botanical origin of the Brazilian propolis types 3 (Southern), 6 (Northeastern) and 12 (Southeastern), has been reported to be resins from Populus sp., Hyptis divaricata and Baccharis dracunculifolia, respectively (1). Brazilian propolis is quite diverse in chemical composition, due to Brazil's rich biodiversity, which needs to be investigated as a source of new bioactive substances, such as cinnamic acid derivatives (2), chiefly artepillin C (3), flavonoids (4) and others with pharmacological or functional properties.

A new type of propolis, named Brazilian red propolis (BRP) because of its color, as yet not classified, was

For reprints and all correspondence: Pedro L. Rosalen, Piracicaba Dentistry School (FOP/UNICAMP), Department of Physiologic

Science, C.P. 52; Zip-code: 13414-903, Piracicaba, SP, Brazil. Tel:+5519-2106-5313; Fax: +55-19-2106-5250; E-mail: rosalen@fop.unicamp.br found in Maceio City (Alagoas state, Northeastern Brazil) and has attracted the attention of international business. So far, this unique propolis has not been found elsewhere in Brazil.

The best approach to finding a plant source of propolis would be by an investigation to compare its chemical composition with that of the supposed plant source and by demonstrating that the source of this propolis is a plant resin, as in the case of red Brazilian propolis.

Thus, the main objective of this study was to identify the plant source and chemical composition of the new Brazilian red propolis, by exploratory phytochemical analysis of the microflora of resins produced in the mangrove area.

\section{Material and Methods}

\section{Plant Propolis and Resin}

Apis mellifera bees from the mangrove region in Marechal Deodoro (a city in the vicinity of Maceio, capital of Alagoas State, in Northeastern Brazil, wet 
tropical climate, SL 09.40 and WL 35.41) were visually monitored and photographically recorded to observe their behavior and vegetational preference in order to determine which plant was visited to collect resin for propolis production. Twenty plant samples (Acrostichum aureum, Anacardium occidentale, Avicennia Germinans, Avicennia schaueriana, Borreria verticillata L. Byrsonima crassifolia, Byrsonima verbascifolia, Canavalia obtusifolia, Cnidosculus urens L. Conocarpus erectus, Cyperus liguralis L. Dalbergia ecastophyllum, Hibiscus pernambucencis, Hibiscus titiaceus, Ipomoea prescapae, Laguncularia racemosa, Paspalum vaginatum, Passiflora subrotunda Mart. Remirea maritima, Rhizophora mangle) were collected after monitoring the bee visits. Propolis produced in the mangrove area was sampled from a collector inside a hive, and samples from all parts of vegetation visited by bees were collected. Plant material taxonomy of the botanical source of propolis was performed in the department of Biological Science of College of Agriculture "Luiz de Queiroz" (University of São Paulo) and a voucher specimen (reference number ESA 96543) was deposited in the herbarium of Biological Science of College of Agriculture 'Luiz de Queiroz' (University of Sao Paulo), Piracicaba, SP, Brazil.

\section{Propolis Extraction}

Propolis was ground to a fine powder and $2 \mathrm{~g}$ (dry weight) were mixed with $25 \mathrm{ml}$ of $80 \%(\mathrm{v} / \mathrm{v})$ ethanol and shaken at $70^{\circ} \mathrm{C}$ for $30 \mathrm{~min}$. After extraction, the mixture was centrifuged and the supernatant was evaporated under low pressure to produce the ethanolic extract of propolis (EEP), which was prepared at $1 \%(\mathrm{p} / \mathrm{v})$ with ethanol $80 \%(\mathrm{v} / \mathrm{v})$.

\section{Resin Extraction}

Resin was extracted immediately after it was removed from the plant shoot surface with a knife. A $10 \mathrm{mg}$ of sample (dry weight) of the resin was mixed with $1 \mathrm{ml}$ of $80 \%(\mathrm{v} / \mathrm{v})$ ethanol to prepare the ethanolic extract of resin (EER). Both EEP and EER were used for chemical analysis.

\section{UV-VIS Spectra}

UV-VIS spectra of the EEP and EER samples were recorded from mixture of $25 \mu \mathrm{l}$ of each extract plus $30 \mathrm{ml}$ of $96 \%$ ethanol. The mixture was scanned at $200-500 \mathrm{~nm}$ by UV-spectrophotometer (UVMini 1240, Shimadzu Co.).

\section{Reversed Phase-High Performance Thin Layer Chromatography (RP-HPTLC)}

Precoated silica gel plates RP-18 $\mathrm{F}_{254} \mathrm{~S}$ were purchased from Merck Co. Six $\mu \mathrm{L}$ of EEP and EER were applied to the lower edge of the plate, and ascending chromatography was run using a mobile phase of ethanol:water (55:45, by v/v). After development, the chromatograms were observed under UV light at $366 \mathrm{~nm}$.

\section{Reversed-Phase High Performance Liquid Chromatography (RP-HPLC)}

EEP and EER were performed by RP-HPLC using a chromatograph equipped with a Shimadzu ODS-A column (RP-18, column size $4.6 \times 250 \mathrm{~mm}$; particle size, $5 \mu \mathrm{m}$ ) and photodiode array detector (SPD-M10AVp, Shimadzu Co.). EEP and EER were filtered with $0.22 \mu \mathrm{m}$ filter (Millipore) prior to $20 \mu \mathrm{l}$ injected into the HPLC system. The column was eluted by using a linear gradient of water (solvent A) and methanol (solvent B), starting with $40 \% \mathrm{~B}$ and increasing to $60 \% \mathrm{~B}(45 \mathrm{~min})$, held at $90 \% \mathrm{~B}(45-75 \mathrm{~min})$, and decreasing to $30 \% \mathrm{~B}$ (75-85 min) with a solvent flow rate of $1 \mathrm{ml} / \mathrm{min}$ and detection with a diode array detector. Chromatograms were recorded at $260 \mathrm{~nm}$ as described by Park et al. (5). The following authentic standards of phenolic acids and flavonoids (Extrasynthese Co.) were examined: $p$-coumaric, ferulic acid, cinnamic acid, gallic acid, quercetin, kaempferol, kaempferide, apigenin, isorhamnetin, rhamnetin, sakuranetin, isosakuranetin, hesperidin, hesperetin, pinocembrin, chrysin, acacetin, galangin, myricetin, tectochrysin and artepillin $\mathrm{C}$.

\section{Gas Chromatography-Mass Spectrometry (GC-MS)}

The EEP and EER samples were chemically analyzed after methylation of the extracts, as described by Markham et al. (6). Samples of the methylated solutions were analyzed by GC-MS by using a CP-Sil 8CB fusedsilica capillary column $(30 \mathrm{~m} \times 0.25 \mathrm{~mm} ; 0.25 \mu \mathrm{m}$ film thickness) installed in a GC (Varian Saturn 2100D) instrument, interfaced to a Varian EM-AI mass selective detector, operated in scanning mode $(\mathrm{m} / \mathrm{z} 40-400)$. The temperature program employed was $50^{\circ} \mathrm{C}(0.3)-285^{\circ} \mathrm{C}$ $(15 \mathrm{~min})$ at a rate of $6^{\circ} \mathrm{C} / \mathrm{min}$, with injection and detector temperatures maintained at 280 and $290^{\circ} \mathrm{C}$, respectively. The split ratio was $20: 1$ with $0.5 \mu 1$ of sample injected (EEP and EER). Carrier gas (He) was $1.0 \mathrm{ml} / \mathrm{min}$. The GC-MS peaks were identified by comparison with data from literature (7) and the profiles from the Nist 98 library.

\section{Results}

\section{Botanical Origin of Red Propolis}

Twenty samples of plants were checked for the possibility of finding botanical origin and tested in our laboratory to compare the chemical profiles of propolis (EEP) and plant resin (EER) in order to select an identical 

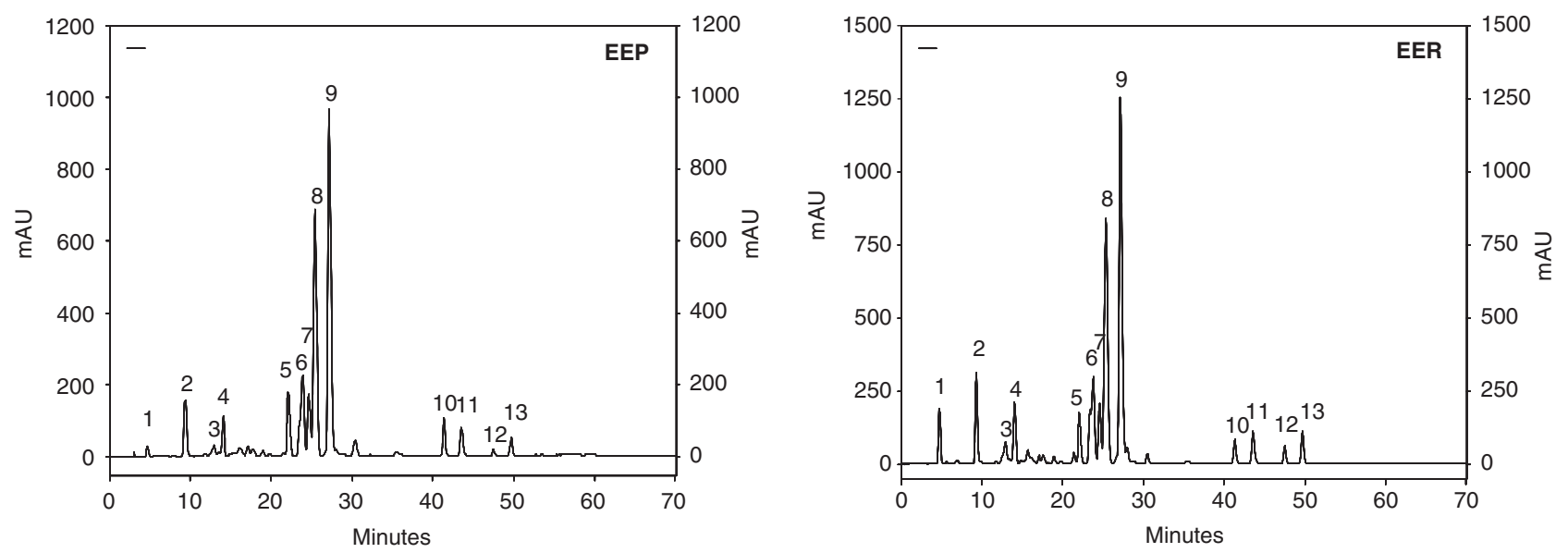

Figure 1. HPLC chromatograms of ethanolic extracts of red propolis (EEP) and Dalbergia ecastophyllum resin (EER). 1, Fereulic acid; 2, UV $\lambda$ 238, $276 \mathrm{~nm}$; 3, Quercetin; 4, UV $\lambda$ 239, $246 \mathrm{~nm}$; 5, UV $\lambda 237,279 \mathrm{~nm}$; 6, UV $\lambda 281,284 \mathrm{~nm} ;$ 7, UV $\lambda 237,279 \mathrm{~nm} ; \mathbf{8}$, UV $\lambda 243,320 \mathrm{~nm}$; 9, UV $\lambda 232$, $261 \mathrm{~nm}$; 10, UV $\lambda$ 246, $265 \mathrm{~nm}$; 11, Chrysin; 12, UV $\lambda$ 246, $324 \mathrm{~nm}$; 13, UV $\lambda 246,265 \mathrm{~nm}$.

Table 1. Relative percentages of compounds, determined by GC/MS, from ethanolic extracts of red propolis and Dalbergia ecastophyllum resin; compounds are referred to by their respective names or mass spectra data (molecular ion and base peak)

\begin{tabular}{llll}
\hline $\begin{array}{l}\text { Retention } \\
\text { time }\end{array}$ & Compounds & \multicolumn{2}{c}{ Relative\% } \\
\cline { 3 - 4 } & & Plant Resin & Propolis \\
\hline 20.24 & $208\left[\mathrm{M}^{+}\right], 193[\mathrm{M}-15]^{+}$ & 0.89 & 2.47 \\
31.62 & $254\left[\mathrm{M}^{+}\right], 223[\mathrm{M}-31]^{+}$ & 0.71 & 0.80 \\
35.64 & $284\left[\mathrm{M}^{+}\right], 253[\mathrm{M}-31]^{+}$ & 1.91 & 6.62 \\
36.10 & Medicarpin & 22.20 & 6.12 \\
37.33 & 3 -Hydroxy-8,9-dimethoxypterocarpan & 61.58 & 67.59 \\
37.80 & $330\left[\mathrm{M}^{+}\right], 300[\mathrm{M}-30]^{+}$ & 1.55 & 2.25 \\
38.00 & $330\left[\mathrm{M}^{+}\right], 300[\mathrm{M}-30]^{+}$isomer & 0.68 & 0.81 \\
38.32 & $330\left[\mathrm{M}^{+}\right], 298[\mathrm{M}-32]^{+}$ & 4.01 & 7.93 \\
38.53 & $330\left[\mathrm{M}^{+}\right], 298[\mathrm{M}-32]^{+}$isomer & 1.03 & 0.83 \\
\hline
\end{tabular}

or similar profile. At first, only one plant showed an EER with profile similar to that of red propolis when compared with RP-HPTLC plate. The plant, locally and popularly identified as rabo-de-bugio (monkey tail), was later identified as Dalbergia ecastophyllum (L.) Taub. Family: Fabaceae (Leguminosae).

\section{Chemical Assays}

The results of UV-VIS spectroscopy, HPLC (Fig. 1) and GC-MS (Table 1) demonstrated that the chemical profile of Dalbergia ecastophyllum was similar to the chemical profile of red propolis. According to GC-MS, the main constituents of both extracts are the isoflavononoids medicarpin and 3-Hydroxy-8,9-dimethoxypterocarpan, the latter representing more than $60 \%$ of the composition in both extracts (Table 1).

\section{Discussion}

The chemical composition of propolis is variable depending on the biodiversity and the geographical origin of this natural substance $(5,8)$.

In this study, a new type of Brazilian propolis, named red propolis, collected from Northeastern Brazil is presented. It has an intense red color and its chemical composition differs from that of the 12 types of Brazilian propolis classified by Park et al. (5).

From the results of UV-VIS spectroscopy, HPLC (Fig. 1) and GC-MS (Table 1), we could observe that not only did EEP and EER present a similar spectral pattern in the region between $200-500 \mathrm{~nm}$, but also the same wavelength of maximum absorption at $282 \mathrm{~nm}$. The EEP and EER analysis using HPLC also demonstrated an identical chemical profile. In addition, we found that the two extracts had at least 12 chemical substances in common, and in similar proportions (Fig. 1). Only two flavonoids (quercetin and chrysin) and one phenolic acid (ferulic acid), identified as standard in the 12 types of Brazilian propolis classified by Park et al. (5), were found in Brazilian red propolis. Absorption spectra obtained with a photodiode detector were used to compare and distinguish peaks. According to the results of the chemical profile obtained with HPLC, it was possible to state that this material proved to be a new type of Brazilian propolis.

The presence of the isoflavononoids medicarpin and 3-Hydroxy-8,9-dimethoxypterocarpan in both extracts is in agreement with Trusheva et al. (9) who also observed the presence of isoflavonoids, such as isosativan and medicarpin, in samples of Brazilian red propolis.

The isoflavonoids are compounds typical of the leguminosae family. Thus, these compounds may be useful as chemical markers of this new type of Brazilian propolis. Several isoflavonoids have already been found in Dalbergia ecastophyllum, among which are medicarpin 
(10), corroborating that this species is the source of resin for the production of Brazilian red propolis.

Brazilian red propolis has a composition similar to that of a specific type of Cuban red propolis, produced in the province of Pinar Del Rio, which has various isoflavonoids, among them medicarpin and 3-Hydroxy8,9-dimethoxypterocarpan (7). Nevertheless, Nepalese propolis also demonstrated to contain various biologically active neoflavonoids, in addition to the presence of the isoflavonoids medicarpin and (+)-vesticarpan (11). There are several studies in the literature, showing that isoflavones have antimicrobial, antifungal, anticancer, osteoporosis, antioxidant action and, relieve the symptoms of menopause. Thus, consumption of foods containing isoflavone phytoestrogens has been associated with a variety of health benefits (12-16).

From the results of UV-VIS spectroscopy, RP-HPTLC, RP-HPLC and GC/MS we conclude that Dalbergia ecastophyllum resin is the botanical source of Brazilian red propolis and that this can be considered a 13th type of Brazilian propolis, complementing the 12 types proposed by Park et al. (5). This is the first time the botanical origin of a type of propolis is reported as occurring in a species of the Leguminosae family, rich in isoflavonoids.

\section{Acknowledgements}

The authors are grateful to Dr Denise M. Pinheiro (Federal University of Alagoas, Maceio, AL, Brazil) and Rubia Solange Soares Barbalho (SEBRAE/AL) for the local technical support. The authors thank FAPESP and $\mathrm{CNPq}$ for the financial support for this research.

\section{References}

1. Park YK, Alencar SM, Aguiar CL. Botanical origin and chemical composition of Brazilian propolis. J Agri Food Chem 2002;50:2502-6.
2. Bankova V, Popov S, Marekov NL. Isopentenyl cinnamates from poplar buds and propolis. Phytochemistry 1989;28:871-3.

3. Kimoto T, Arai S, Koguchi M, Aga M, Nomura Y, Micallef MJ, et al. Apoptosis and suppression of tumor growth by artepillin $\mathrm{C}$ extracted from Brazilian propolis. Cancer Detect Prev 1998;22:506-15.

4. Bankova V, Popov S, Marekov NL. High performance liquid chromatographic analysis of flavonoids from propolis. J Cromatog 1982;242:135-43.

5. Park YK, Paredes-guzman JF, Aguiar CL, Alencar SM, Fujiwara FY. Chemical constituents in Baccharis dracunculifolia as the main botanical origin of southeastern Brazilian propolis. J Agric. Food Chem 2004;52:1100-03.

6. Markham KR, Mitchel KA, Wilkins AL, Daldy JA, Lu Y. HPLC and GC-MS identification of the major organic constituents in New Zealand propolis. Phytochemistry 1996;42:205-11.

7. Piccinelli AL, Campo Fernandez M, Cuesta-Rubio O, Hernandez IM, De Simone F, Rastrelli L. Isoflavonoids isolated from Cuban propolis. J Agric Food Chem 2005;53:9010-16.

8. Christov R, Trusheva B, Popova M, Bankova V, Bertrand M. Chemical composition of propolis from Canada, its antiradical activity and plant origin. Nat Prod Res 2005;19:673-8.

9. Trusheva B, Popova M, Bankova V, Simova S, Marcucci MC, Miorin PL, et al. Bioactive constituents of Brazilian red propolis. Evid based Complem Altern Med 2006;3:249-54.

10. Matos FJA, Gottlieb OR, Andrade CHS. Flavanoids of Dalbergia ecastophyllum. Phytochemistry 1975;14:825-6.

11. Awale S, Shrestha SP, Tezuka Y, Ueda J, Matsushige K, Kadota S. Neoflavonoids and related constituents from Nepalese propolis and their nitric oxide production inhibitory activity. J Nat Prod 2005;68:858-64.

12. Wang W, Weng XC, Cheng DL. Antioxidant activities of natural phenolic components from Dalbergia odorifera T. Chen. Food Chem 2000;71:45-9.

13. Militao GCG, Jimenez PC, Wilke DV, Pessoa C, Falcao MJC, Lima MAS, et al. Antimitotic properties of pterocarpans isolated from Platymiscium floribundum on sea urchin eggs. Planta Med 2005;71:683-5.

14. Militao GCG, Dantas INF, Pessoa C, Falcao MJC, Silveira ER, Lima MAS. Induction of apoptosis by pterocarpans from Platymiscium floribundum in HL-60 human leukemia cells. Life Sci 2006;78:2409-17.

15. Rufer CE, Kulling SE. Antioxidant activity of isoflavones and their major metabolites using different in vitro assays. $\mathrm{J} \mathrm{Agr} \mathrm{Food} \mathrm{Chem}$ 2006;54:2926-31.

16. Kano M, Takayanagi T, Harada K, Sawada S, Ishikawa F. Bioavailability of isoflavones after ingestion of soy beverages in healthy adults. $J$ Nutr 2006;136:2291-6.

Received November 16, 2006; accepted April 9, 2007 


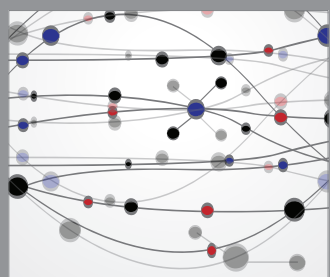

The Scientific World Journal
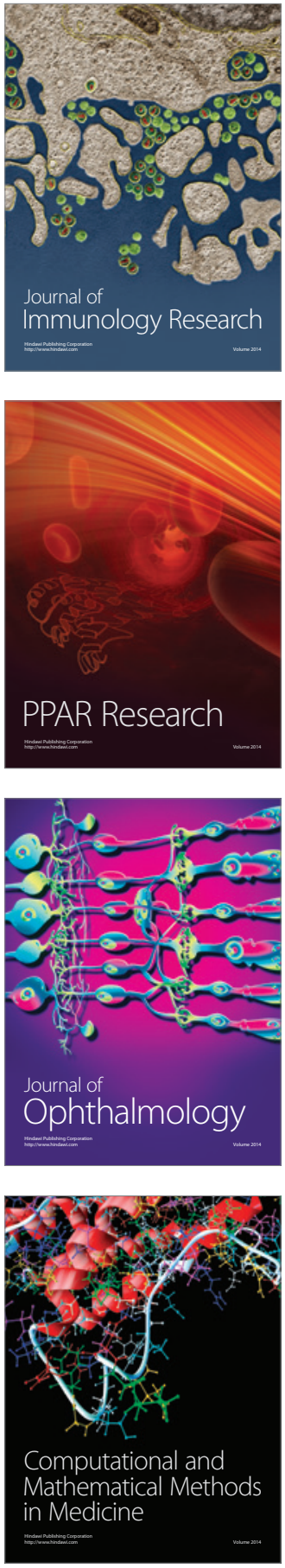

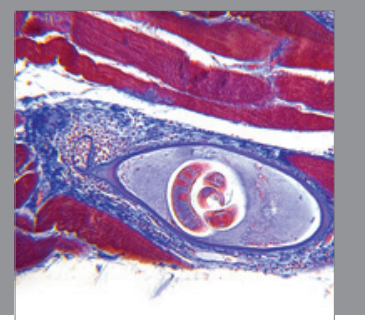

Gastroenterology

Research and Practice
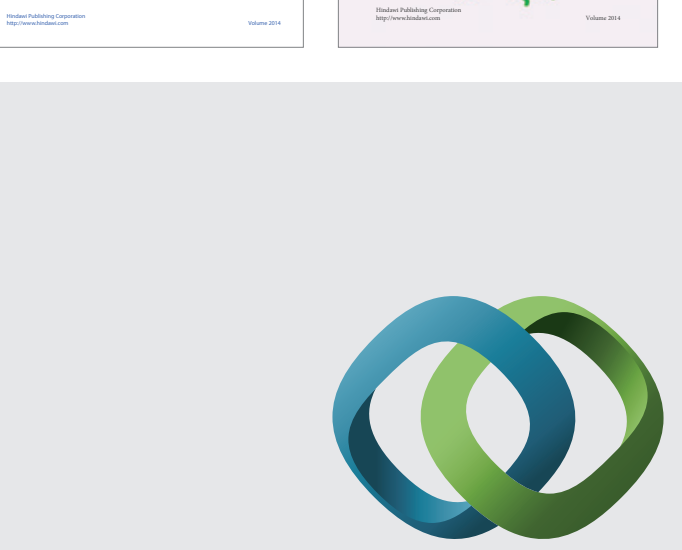

\section{Hindawi}

Submit your manuscripts at

http://www.hindawi.com
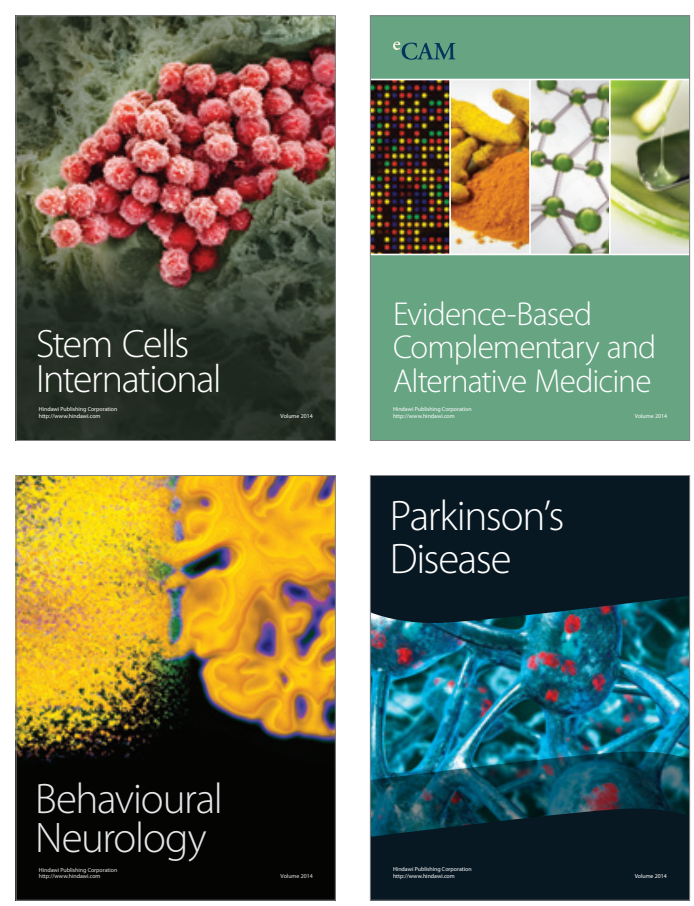

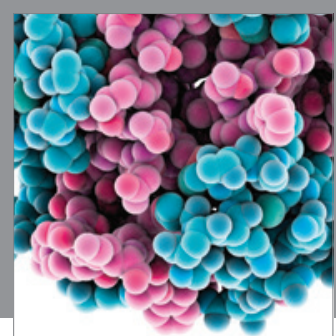

Journal of
Diabetes Research

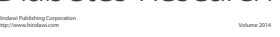

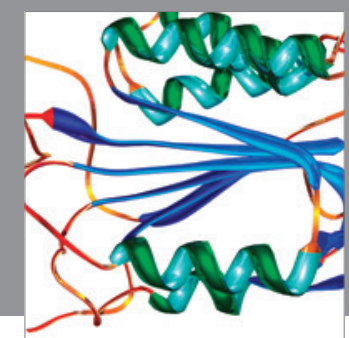

Disease Markers
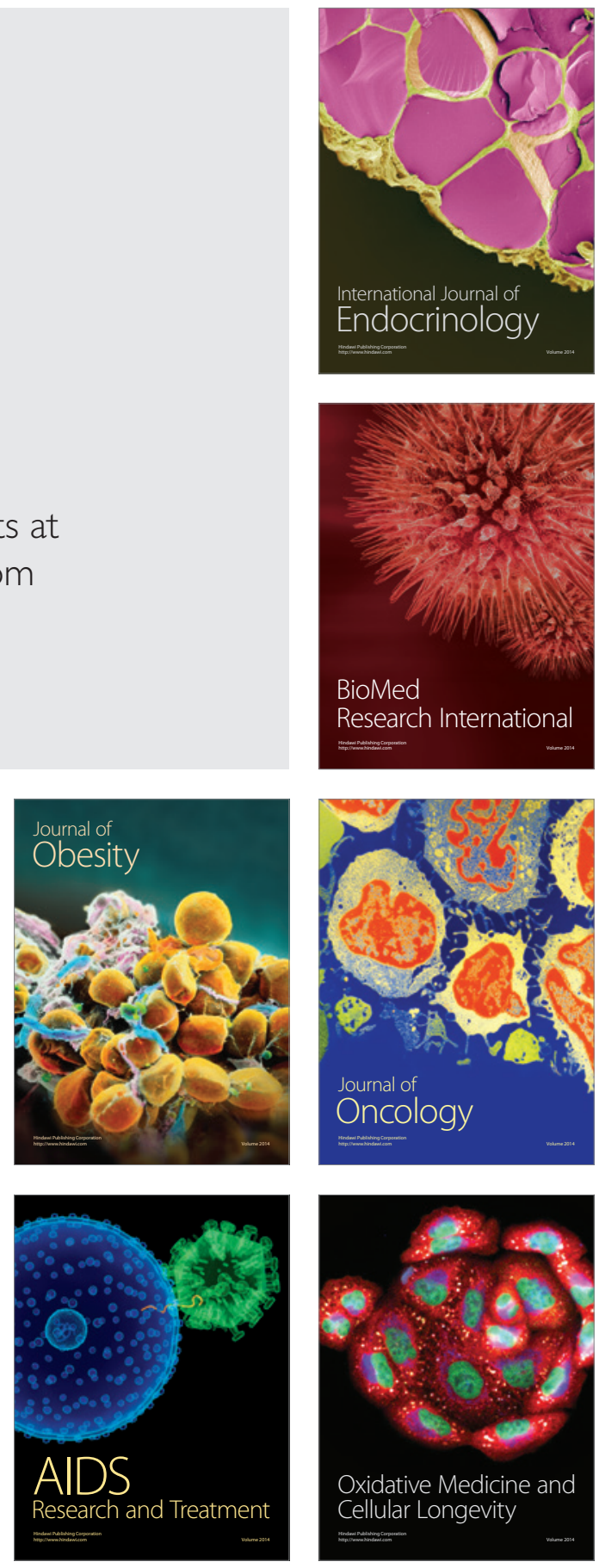